УДК 342.9:351.746.1(477)

DOI https://doi.org/10.32844/2618-1258.2019.3-1.34

\title{
ОЛИцький О.М.
}

\section{ОЗНАКИ ПІДРОЗДІЛІВ ШВИДКОГО РЕАГУВАННЯ ДЕРЖАВНОЇ ПРИКОРДОННОЇ СЛУЖБИ УКРАЇНИ}

Стаття присвячена з'ясуванню ознак підрозділів швидкого реагування Державної прикордонної служби України. На підставі аналізу нормативно-правових актів та наукової літератури встановлено, що підрозділам швидкого реагування Державної прикордонної служби України притаманні такі ознаки:

- мета створення, завдання, повноваження, тактика та способи дій, вимоги до кандидатів є відмінними, особливими, рідкісними від аналогічних підстав (умов) для інших підрозділів, які структурно функціонують у Державній прикордонній службі України;

- переважно застосовуються раптово у складних та кризових ситуаціях,

- діяльність спрямована на усунення причин та умов, що посягають на національну й прикордонну безпеку держави;

- застосовуються на будь-якій частині території України, пов'язаній із проходженням лінії державного кордону, отже, відсутня прив'язка до постійного місця розташування підрозділу, на відміну від інших підрозділів, які функціонують на визначеній ділянці відповідальності;

- підвищені вимоги до комплектування підрозділу, зокрема до фізичної, інтелектуальної та психологічної складових частин;

- складна та насичена програма підготовки персоналу, в тому числі практична частина (тренінги), що складає більшість службового часу;

- беруть участь у спеціальних прикордонних операціях;

- спроможність чітко, злагоджено взаємодіяти з основними підрозділами охорони державного кордону і з підрозділами військових формувань, правоохоронних органів України та країн-партнерів;

- спроможність сил та засобів таких підрозділів у протидії злочинності чи іншій загрозі значно перевищує можливості основного підрозділу.

Автором зроблено висновок, що підрозділи швидкого реагування - це структурні підродили Державної прикордонної служби України, призначення яких зумовлене ускладненням обстановки на державному кордоні та необхідністю підсилення основних підрозділів, а методи та способи дій цих підрозділів спрямовані на силову реалізацію службово-бойової діяльності.

Запропоновано розробити та прийняти загальне Положенням про спеціальні підрозділи ДПСУ із чіткою фіксацією переліку цих підрозділів, їхніх завдань, принципів та форм діяльності, визначення місця цих підрозділів у загальній структурі ДПСУ, таким чином визначити їхній правовий статус.

Ключові слова: Державна прикордонна служба Украӥни, підрозділи швидкого реагування, охорона державного кордону, прикордонна безпека.

The article considers justification of the characteristic features of the rapid response units of the State border guard service of Ukraine. Based on the analysis of the legal acts and scientific literature it was found out that the rapid response units of the State border guard service of Ukraine are characterized by the following features:

- the purpose of creation, tasks, powers, tactics and methods of action, requirements to candidates are different, special, rare from the similar bases (conditions) for other units, which structurally function in the State border guard service of Ukraine;

- they are mainly used in complex and crisis situations,

(с) ОЛИЦьКИЙ О.М. - ад’юнкт (Національна академія Державної прикордонної служби України імені Богдана Хмельницького) 
- the activity is aimed at eliminating the causes and conditions that encroach on the national and border security of the state;

- they are used in any part of the territory of Ukraine associated with the state border line, therefore there is no binding to the place of permanent location of the unit, unlike other units that operate in a certain area of responsibility;

- increased requirements for the personnel of the units, in particular the physical, intellectual and psychological component;

- a complex and tough program of personnel training, including the practical part (trainings), which makes up the majority of working time;

- participation in special border guard operations;

- the ability to interact clearly and harmoniously with the main units of the state border protection and with the interacting units of military formations, law enforcement agencies of Ukraine and partner countries;

- ability of forces and means of such units to counteract crime or other threat, which considerably exceeds possibilities of the main units.

The author concluded that rapid response units are structural units of the State border guard service of Ukraine, the purpose of which is grounded by complication of the situation on the state border and the need to strengthen the basic units, and methods and ways of action of these units is directed to force performing of service-combat activity.

It is proposed to develop and adopt a General Regulation on special units of the SBGSU with a clear stating of the list of these units, their tasks, principles and forms of activity, determining the place of these units in the overall structure of the SBGSU, thus determining their legal status.

Key words: State border guard service of Ukraine, rapid response units, state border protection, border security.

Вступ. Тривале загострення на сході країни, постійна зміна характеру (військове, злочинно-протиправне), тактики, способів дій порушників прикордонного законодавства зумовлює створення нетипових загроз прикордонній безпеці. Достатньо адаптований до умов сьогодення рівень підготовки усього персоналу Державної прикордонної служби України (далі - ДПСУ) відповідає вимогам іiї повсякденної оперативно-службової діяльності. Тобто професіоналізм військовослужбовців, що фахово підготовлені для забезпечення прикордонної служби, прикордонного контролю та оперативно-розшукової діяльності, здатен забезпечити виконання основних функцій ДПСУ. Разом із тим у повсякденній діяльності, як показує досвід та історія розвитку прикордонної охорони держави, виникають нестандартні (нештатні) ситуації, які потребують знання, сил та навичок діяти за особливих умов та вирішувати надскладні завдання. Для цього використовуються підрозділи, що виконують спеціальні завдання, безпосередньо призначені та підготовлені для них.

Постановка завдання. Зважаючи на достатньо невеликий термін існування підрозділів спеціального призначення ДПСУ, сьогодні вже є наукові праці, які присвячені різним питанням функціонування даних підрозділів. У цих працях розглянуто математичну модель задачі формування складу транспортної колони прикордонної комендатури швидкого реагування та ії програмно-алгоритмічну реалізацію (О.В. Боровик); проаналізовані сучасні погляди на ведення стабілізаційних операцій, які визначають характер завдань прикордонних підрозділів швидкого реагування під час участі у стабілізаційних діях військ (сил) (О.П. Глуздань); розроблені рекомендації щодо організації матеріально-технічного забезпечення дій прикордонного підрозділу швидкого реагування під час загострення воєнно-політичної обстановки (А.С. Курашкевич), обгрунтовані методичні підходи до підготовки тактичних навчань із підрозділами швидкого реагування ДПСУ (В.В. Крутов), запропоновані рекомендації начальнику органу охорони державного кордону щодо планування застосування прикордонного підрозділу швидкого реагування під час загострення воєнно-політичної обстановки (В.В. Лемешко), роль та місце підрозділів спеціального призначення в умовах збройних локальних конфліктів (А.В. Братко) тощо. При цьому поза увагою наукового пізнання залишається дослідження правого статусу, поняття, різновидів, ознак підрозділів спеціального призначення ДПСУ, які призначені для швидкого реагування на загострення обстановки на державному кордоні, що буде здійснено у цьому підрозділі. 
Метою статті є здійснення правового аналізу ознак підрозділів швидкого реагування
ДПСУ.

Результати дослідження. Сьогодні з урахуванням широкого використання термінів «спеціальний підрозділ», «підрозділ для виконання спеціальних завдань» у законодавстві, у практичній діяльності правоохоронних органів та в повсякденному обігу відзначимо відсутність науково розробленого та законодавчо визначеного підходу до даної термінології.

Ключовим словом у цих термінологічних конструкціях є слово «спеціальний», яке у Словнику української мови розтлумачується як призначений виключно для кого-, чого-небудь; який має особливе призначення; який чимсь виділяється серед інших; не такий, як інші; особливий; який відзначається більшою, ніж звичайно, мірою свого вияву [1, с. 501]. Аналогічне значення терміна «спеціальний» надається у Великому тлумачному словнику сучасної української мови В.Т. Бусела. Крім того, у цьому ж словнику надається трактування поняття «спеціально» як прислів'я до «спеціальний»: поглиблено, професійно, як спеціаліст; із певною метою, з певним наміром, навмисно; тільки виключно [2, с. 1364].

Отже, поняття «спеціальний» чи «призначені спеціально для виконання конкретного завдання» стосуються підрозділів ДПСУ, що наділені окремими від усієї ії функціональної системи властивостями, винятковими завданнями, навиками персоналу.

Для спеціальних підрозділів властивий не тільки «здоровий», але і достатньо високий, стійкий морально-психологічний клімат як усього колективу, так і індивідуально кожного його представника, адже нестандартні кризові ситуації завжди є підвищено непередбачувані, потребують психологічної стійкості.

«Спеціального призначення частини і підрозділи» у Юридичній енциклопедії узагальнено як: по-перше, особливі частини і підрозділи, призначені для проведення у кризових ситуаціях чи 3 початком війни розвідувальних та інших таємних операцій на території іноземної держави або в тилу противника; по-друге, силові підрозділи спецслужб і поліцейських сил, призначені для звільнення заручників, припинення терористичних акцій, ліквідації незаконних збройних формувань і організованих злочинних угруповань [3, с. 585]. У даному контексті наголошується на особливих завданнях спеціальних підрозділів із приборкання чи взяття під контроль надзвичайних кризових ситуацій. Основні повноваження підрозділів спеціального призначення зводяться до того, що вини виконують ті завдання, які виходять за межі повсякденної службової діяльності усього персоналу, що втілюють в життя основне призначення ДПСУ, уособлене в основних видах оперативно-службової діяльності, таких як: прикордонний контроль, прикордонна служба та оперативно-розшукова діяльність.

У разі ускладнення обстановки охорона державного кордону переводиться на посилений режим, для цього за рішенням відповідного командира (начальника) можуть проводитися спеціальні заходи з метою усунення причин та ліквідації наслідків ускладнення обстановки. Основною силою, що здійснює спеціальні заходи, є дії резервів [4, с. 6].

А.В. Братко називає підрозділи, що виконують спеціальні завдання в особливих умовах, зокрема у вирішенні локальних збройних конфліктів, безпосередніми виконавцями [5, с. 47]. Таку позицію науковець пояснює усвідомленням необхідності вирішення локальних конфліктів ефективними діями обмеженого контингенту без використання важкого озброєння [5, с. 48]. О3броїти суперсучасною зброєю можна будь-який підрозділ, як пише автор, а для спеціальних підрозділів це поєднюється з якісним особовим складом. Беззаперечною умовою ефективності дій спецпідрозділу є хороші дані кандидата в підрозділи спецпризначення, фізичні можливості, інтелектуальний потенціал та психічний стан, що дозволять опанувати складну та насичену програму підготовки в порівнянні з іншими підрозділами [5, с. 48]. Ще однією властивістю спеціальних підрозділів $є$ їхня спроможність та можливість діяти у відриві від основних сил, що неможливо без якісної підготовки персоналу цих підрозділів (у тому числі психологічної та тактичної) та адекватного озброєння [5, с. 50].

Сучасні підрозділи спеціального призначення застосовуються в спеціальних заходах залежно від цілей та завдань, таких як:

1) ведення спеціальної розвідки об'єктів противника;

2) ведення спеціальних (спеціальних бойових) дій у тилу противника як у мирний час, так і під час збройного конфлікту;

3) проведення диверсій та організація осередків партизанського руху в тилу противника;

4) проведення спеціальних, психологічних, інформаційних та пошуково-рятувальних операцій; 
5) участь у ліквідації наслідків природних та техногенних катастроф;

6) координація проведення військових операцій з іноземними цивільними офіційними особами, цивільними установами країни і міжнародними неурядовими та приватними організаціями;

7) забезпечення безпеки судноплавства;

8) надання допомоги іноземним державам у забезпеченні їхньої внутрішньої безпеки;

9) збір інформації в ході миротворчих операцій [5, с. 50].

Характерною особливістю підрозділів спеціального призначення $є$ їхні завдання та мета створення, що порівнюються із призначенням інших основних підрозділів ДПСУ. Для того щоб визначити якісне місце цих підрозділів, зробимо системний огляд їхнього правового статусу.

Поняття «правовий статус» не $\epsilon$ новим у теорії права, але і до сьогодні немає єдиного розуміння його сутності. Так, правовий статус, як його тлумачить Український юридичний термінологічний словник, - це встановлене нормами права положення його суб'єктів, сукупність їхніх прав і обов'язків [6].

Спираючись на позицію А.П. Альохіна [7, с. 106], Д.В. Мандичев під правовим статусом розуміс складну правову конструкцію, що включає такі елементи, як: цілі, завдання, функції, компетенція, організаційний блок елементів та відповідальність [8, с. 112]. Щодо відповідальності, то вона є загальною для всіх структурних підрозділів ДПСУ та їхнього особового складу, тобто настає за невиконання або неналежне виконання своїх обов'язків чи наказів начальників. Вважаємо, що відповідальність не характеризує в даному випадку статус дослідженого підрозділу.

Для визначення правового статусу державного органу А.Т. Комзюк вважає за необхідне 3'ясувати його місце в загальній системі виконавчої влади, рівень і форму його правового регулювання; визначити межі його відання, визначити сферу суспільних відносин, які регулюються даним органом, перелічити об'єкти, йому підпорядковані, з'ясувати коло завдань, на нього покладених, сукупність прав і обов'язків (правомочностей) та його посадових осіб під час виконання покладених на орган функцій, тобто визначити міру, можливої поведінки органу та його посадових осіб під час виконання ними своїх функцій (права), а також міру їхньої обов'язкової поведінки (обов'язки) [9, с. 63].

Існує позиція авторів, які розглядають правовий статус суб'єктів права через їхню правосуб' єктність, тобто включають у правовий статус призначення органів, їхні завдання, функції, компетенцію і повноваження, форми, методи та цілі діяльності [7].

Отже, проаналізовані погляди щодо змісту правого статусу дозволяють нам визначити елементи, які, на наш погляд, можуть розкрити правовий статус підрозділів спеціального призначення ДПСУ, а саме: місце в системі ДПСУ, призначення, завдання і повноваження.

Виходячи із загального розуміння категорії «правовий статус» в юридичній науці, адміністративно-правовий статус - це регламентоване нормами адміністративного права становище, яке характеризується сукупністю прав, обов'язків, гарантій діяльності [10, с. 20]. При цьому Б.М. Ринажевський підкреслює, що у юридичній літературі існують і такі поняття, як «спеціальний правовий статус» [10, с. 18]. Під поняттям «спеціальний» можна розуміти: призначений виключно для кого-, чого-небудь; який має особливе призначення; який чимсь виділяється серед інших; не такий, як інші; особливий; який відзначається більшою, ніж звичайно, мірою свого вияву [10].

ДПСУ має свою структуру, що забезпечує виконання завдань, поставлених перед прикордонним відомством державою [11]. Стаття 6 Закону України «Про Державну прикордонну службу України» визначає загальну структуру та чисельність ДПСУ. Крім загальної структури, у згаданій вище статті закріплено, що у системі ДПСУ є і підрозділи спеціального призначення [12, ч. 4 ст. 6]. До складу основної оперативно-службової ланки ДПСУ, на яку покладаються охорона певної ділянки державного кордону - прикордонного загону [12, ч. 10 ст. 6], можуть входити прикордонні комендатури, відділи прикордонної служби, прикордонні застави, контрольно-пропускні пункти, відділення прикордонного контролю [12, ч. 3 ст. 10]. В.Л. Зьолка підкреслює, що законодавець використовує словосполучення «можуть входити», а це свідчить про те, що на рівні Закону визначається орієнтовний перелік елементів прикордонного загону. Це, у свою чергу, створює можливості для реформування системи ДПСУ [13, с. 153]. Тим самим надаються можливості своєчасно змінювати чи реформувати структурні підрозділи ДПСУ у зв'язку з наявністю чи відсутністю відповідних загроз у прикордонній сфері, у межах системи органів виконавчої влади які координують діяльність відомства.

Адміністрація ДПСУ, посідаючи визначене місце в системі центральних органів виконавчої влади [14], має статус органу, що реалізує державну політику у сфері захисту державного 
кордону та охорони суверенних прав України в іiі виключній (морській) економічній зоні $[15$, п. 1]. АДПСУ є суб'єктом адміністративно-правових відносин як орган держави поряд 3 іншими (Президент України, органами виконавчої влади тощо) органами. Державний орган створюється для здійснення визначеного виду державної діяльності, який залежить від предмета відання, поставлених завдань та виконуваних функцій. Такий орган, будучи первинною ланкою механізму держави, який внаслідок своєї діяльності реалізує ту чи іншу ії функцію, має ряд специфічних ознак, що виокремлюють його серед інших структурних елементів вказаного механізму. Таким чином, підрозділи спеціального призначення ДПСУ продовжують правовий статус АДПСУ, при цьому мають свої відокремлені власні завдання в межах діяльності системи органів охорони державного кордону.

У ст. 6 Закону України «Про державну прикордонну службу України» представлена загальна структура ДПСУ, до якої відносяться:

- центральний орган виконавчої влади, що реалізує державну політику у сфері охорони державного кордону;

- територіальні органи центрального органу виконавчої влади, що реалізує державну політику у сфері охорони державного кордону;

- Морська охорона, яка складається із загонів морської охорони;

- органи охорони державного кордону - прикордонні загони, окремі контрольно-пропускні пункти, авіаційні частини;

- розвідувальний орган центрального органу виконавчої влади, що реалізує державну політику у сфері охорони державного кордону [12, ст. 6].

На момент прийняття цього Закону (03.04.2003р.) прикордонна служба реформувалась у правоохоронний орган в умовах відсутності реальної військової загрози, а також загрози діяльності терористичних угрупувань, тому відсутнє визначення місця підрозділів спеціального призначення у структурі ДПСУ. Це можна пояснити і відсутню (на момент прийняття Закону) такої кількості спецпідрозділів, чисельності спецпризначенців у таких підрозділів, підстав застосування, які існують. За період 2003-2019 рр. їхній склад та якість значно зросли.

Для порівняння: в Законі України «Про Національну поліцію» від 2 липня 2015 року встановлено, що у складі поліції функціонують спеціальна поліція та поліція особливого призначення [16, п. 5, 6 ч. 3 ст. 13]. У Положенні про загони спеціального призначення Національної гвардії України, затвердженому наказом Міністерства внутрішніх справ України 20 грудня 2018 року № 1036, чітко визначено, що ці загони застосовуються в умовах підвищеного ризику для життя та здоров'я військовослужбовців, що потребує від особового складу високого рівня професійної підготовки. Ці загони призначені для вжиття заходів щодо захисту та охорони життя, прав, свобод і законних інтересів громадян, суспільства і держави від злочинних посягань, охорони громадського порядку та забезпечення громадської безпеки, оперативного реагування на дії незаконних воєнізованих або збройних формувань (груп), терористичних організацій, організованих груп та злочинних організацій, припинення терористичної діяльності [17, п. 2].

Вважаємо, що підрозділи спеціального призначення мають бути окремим елементом в організаційній структурі ДПСУ, тому ст. 6 Закону України «Про державну прикордонну службу України» потребує доповнення ще однією частиною.

Ще більш суперечливими $є$ положення статті 12. «Підрозділи спеціального призначення» Закону України «Про Державну прикордонну службу України», яка визначає, що у складі центрального органу виконавчої влади, що реалізує державну політику у сфері охорони державного кордону, територіальних органів центрального органу виконавчої влади, що реалізує державну політику у сфері охорони державного кордону, органів охорони державного кордону - функціонують підрозділи спеціального призначення: оперативного документування, оперативно-технічні, забезпечення внутрішньої безпеки та власної безпеки. Ці підрозділи здійснюють діяльність у межах одного з видів оперативно-службової діяльності (далі - ОСД), оскільки забезпечують ії результативність та керуються нормами Закону України «Про оперативно-розшукову діяльність». Тому досить дивно, на наш погляд, вважати одну з основних форм діяльності спеціальною, такою, що відрізняється від основних задач, не такою, як інші. Безперечно, кожна із форм ОСД має свої особливості, але вони здійснюються постійно, щоденно, безперервно і спрямовані на дотримання прикордонного законодавства та виконання основних завдань та функцій ДПСУ. Що не скажеш про діяльність спеціальних підрозділів, які застосовуються в разі виникнення кризової ситуації та потребують швидкого реагування, особливих навичок персоналу, їхніх злагоджених дій, спеціального обладнання, зброї, спеціальних засобів тощо. Передбачені у ст. 12 згаданого 
закону спеціальні підрозділи не забезпечують усунення чи ліквідацію кризових ситуацій, нейтралізацію диверсантів, терористів, припинення терорист, акцій, ліквідацію незаконних збройних формувань і організованих злочинних угруповань тощо. Тому їх (підрозділи оперативного документування, оперативно-технічні, забезпечення внутрішньої безпеки та власної безпеки) не можна вважати підрозділами спеціального призначення

У нормативних та доктринальних джерелах зустрічаються різні терміни відносно таких спеціальних підрозділів: «підрозділи швидкого реагування», «резерви», «мобільні підрозділи». На нашу думку, загальною об'єднуючою назвою цих підрозділів може бути «підрозділи швидкого реагування ДПСУ», під якими ми розуміємо підрозділи ДПСУ, що володіють спеціальним правовим статусом, призначені для реагування на загострення та ускладнення обстановки на прикордонних територіях, усунення їхніх умов та підстав. Така ж назва застосовується до спеціальних підрозділів у Стратегії розвитку Державної прикордонної служби (до 2020 року) (далі - Стратегія), схваленій розпорядженням Кабінету Міністрів України (від 23.11.2015 № 1189-р) [18]. Зокрема, у Стратегії для формування та забезпечення розвитку підрозділів швидкого реагування передбачається:

1) утворення підрозділів швидкого реагування, оснащення їх сучасними зразками озброєння, військової та спеціальної техніки;

2) нарощування бойової і мобільної спроможності з урахуванням цільового призначення, створення запасів необхідних ресурсів для відновлення боєздатності;

3) удосконалення порядку дій підрозділів швидкого реагування, підвищення рівня їх боєздатності [18].

Висновки. Отже, для підрозділів швидкого реагування ДПСУ характерні такі ознаки:

- мета створення, завдання, повноваження, тактика та способи дій, вимоги до кандидатів $\epsilon$ відмінними, особливими, рідкісними від аналогічних підстав (умов) для інших підрозділів, які структурно функціонують у ДПСУ;

- переважно застосовуються раптово у складних та кризових ситуаціях,

- діяльність спрямована на усунення причин та умов, що посягають на національну і прикордонну безпеку держави;

- застосовуються на будь-якій частині території України, пов’язаній із проходженням лінії державного кордону, отже, відсутня прив'язка до постійного місця розташування підрозділу, на відміну від інших підрозділів, які функціонують на визначеній ділянці відповідальності;

- підвищені вимоги до комплектування підрозділу, зокрема до фізичної, інтелектуальної та психологічної складових частин;

- складна та насичена програма підготовки персоналу, в тому числі практична частина (тренінги), що складає більшість службового часу;

- беруть участь у спеціальних прикордонних операціях;

- спроможність чітко злагоджено взаємодіяти з основними підрозділами охорони державного кордону і з підрозділами військових формувань правоохоронних органів України і країн-партнерів;

- спроможність сил та засобів таких підрозділів у протидії злочинності чи іншій загрозі значно перевищує можливості основного підрозділу.

Варто запропонувати розробити та прийняти загальне Положення про спеціальні підрозділи ДПСУ із чіткою фіксацією переліку цих підрозділів, їхніх завдань, принципів та форм діяльності, визначення місця цих підрозділів у загальній структурі ДПСУ, таким чином визначити їхній правовий статус. Це і $є$ перспективою подальших наукових досліджень у даному напрямку.

\section{Список використаних джерел:}

1. Словник української мови : в 11 томах. T. 9, 1978. URL : http://sum.in.ua/s/specialjnyj.

2. Великий тлумачний словник сучасної української мови : / уклад. та голов. ред. В.Т. Бусел. Київ ; Ірпінь : Перун, 2005. VIII, 1728 с.

3. Юридична енциклопедія : в 6 т. / за ред. Ю.С. Шемшученко, та ін. Київ : Укр. енцикл., 1999. Т. 5. : П-С. 736 c.

4. Боровик О.В., Березенський О.І. Базова модель підтримки прийняття рішення начальником відділу прикордонної служби щодо розподілу сил та засобів для організації спостереження в межах ділянки відповідальності. Збірник наукових праць НАДПСУ. Хмельницький : НАДПСУ, 2007. № 42. Ч. 2. С. 6-9.

5. Братко А.В. Роль та місце підрозділів спеціального призначення в умовах збройних локальних конфліктів. Збірник наукових працьь Національної академії Державної прикордонної 
служби Украӥни. Сер. : Військові та технічні науки. Хмельницький : Вид-во НАДПСУ, 2017. № 4(74). С. 46-57.

6. Правовий статус : Український юридичний термінологічний словник URL : $/ \mathrm{http} / / /$ www.marazm.org.ua/document/termin/index.php?file=\%CF\%F0\%E0\%E2\%EE\%E2\%E8\%E9\%20 $\% \mathrm{~F} 1 \% \mathrm{~F} 2 \% \mathrm{E} 0 \% \mathrm{~F} 2 \% \mathrm{~F} 3 \% \mathrm{~F} 1 . t \mathrm{xt}$.

7. Алехин А.П. Административная ответственность за правонарушения на транспорте. Москва, 1967. С. 140.

8. Мандичев Д.В. Загальна характеристика адміністративно-правового статусу державної інспекції з контролю якості лікарських засобів. Вісник Академії митної служби Украӥни. Серія : Право. 2009. № 2(3). С. 108-113.

9. Комзюк В.Т. Адміністративно-правові засоби здійснення митної справи : дис. ... канд. юрид. наук. Харків, 2003. 196 с.

10. Ринажевський Б.М. Компетенція та повноваження військової служби правопорядку (служби правопорядку) у ЗСУ. Право і безпека. 2010. № 1. С. 15-21.

11. Ляшук Р.М. Визначення змісту поняття «організаційна структура відділів прикордонної служби». Науковий вісник Херсонського держ. університету. Сер. : Юридичні науки. Херсон, 2014. № 4. T. 2. С. 74-76.

12. Про Державну прикордонну службу України : Закон України від 3 квітня 2003 року. Відомості Верховної Ради України. 2003. № 27. Ст. 208.

13. Зьолка В.Л. Охорона національних інтересів України у прикордонній сфері (адміністративно-правовий аспект) : монографія. Хмельницький, 2015. 672 с.

14. Про оптимізацію системи центральних органів виконавчої влади : постанова Кабінету Міністрів України від 10 вересня 2014 року № 442. Офіційний вісник Украӥни. 2014. № 74. Ст. 2105 .

15. Положення про Адміністрацію Державної прикордонної служби України : постанова Кабінету Міністрів України від 16 жовтня 2014 р. № 533. Офіиійний вісник Украӥни. 2014. № 85. Ст. 2390.

16. Про Національну поліцію : Закон України від 2 липня 2015 року № 580-VIII. Вiдомості Верховної Ради. 2015. № 40-41. Ст. 379.

17. Положення про загони спеціального призначення Національної гвардії України : наказ Міністерства внутрішніх справ України 20 грудня 2018 року № 1036. URL : https://zakon.rada.gov. ua/laws/show/ru/z0021-19.

18. Про схвалення Стратегії розвитку Державної прикордонної служби України : розпорядження Кабінету Міністрів України від 23 листопада 2015 р. № 1189-р. Урядовий кур’єр. 2015. № 220 . 